\title{
Bazı Ahududu Çeşitlerinin Yozgat Ekolojisinde Adaptasyon Yeteneklerinin Belirlenmesi
}

\author{
Gülden BALCI 1(iD), Hakan KELES $2^{\circ}$ (iD \\ 1,2Yozgat Bozok Üniversitesi, Ziraat Fakültesi, Bahçe Bitkileri Bölümü, 66200, Yozgat/Merkez \\ ${ }^{1}$ https://orcid.org/0000-0001-7108-4887, ${ }^{2}$ https://orcid.org/0000-0002-8225-931X \\ $\bowtie$ : hakan.keles@bozok.edu.tr
}

\section{ÖZET}

Bu çalışma 2017-2018 yıllarında Heritage, Aksu Kırmızısı, Hollanda Boduru ve Ruby ahududu çeşitlerinin Yozgat ekolojik koşullarına adaptasyon yeteneklerinin belirlenmesi amacıyla yürütülmüştür. Çeşitlerin performansları fenolojik gözlemler, bitkisel özellikler ve bazı meyve kalite kriterleri incelenerek değerlendirilmiştir. Sürgün başına verim bakımından Heritage çeşidi her iki yıl için en iyi sonuçları (177.85 - $337.34 \mathrm{~g}$ adet $\left.^{-1}\right)$ vermiştir. Ortalama meyve ağırlıkları bakımından denemenin ilk yılı istatistiki açıdan bir fark bulunamamış ancak ikinci yıl Ruby (2.32 g) ve Aksu Pembesi (2.21 g) aynı grupta yer alarak en yüksek ortalama meyve ağırlığına sahip çeşitler olmuşlardır. Suda çözünür kuru madde, titre edilebilir asitlik ve $C$ vitamini bakımından öne çıkan çeşit Heritage olmuştur.

Denemenin iki yılında alınan sonuçlar değerlendirildiğinde istatistiki açıdan Aksu Pembesi çeşidinin vejetatif büyüme açısından bölgeye diğer çeşitlere göre daha hızlı uyum sağladığı belirlenmiştir. Verim ve kalite değerleri açısından ise Heritage çeşidinin diğer çeşitlere kıyasla istatistiki olarak en yüksek sonuçlara sahip çeşit olduğu belirlenmiştir.

\section{Araştırma Makalesi}

Makale Tarihçesi

Geliş Tarihi : 26.02 .2019

Kabul Tarihi : 16.05 .2019

\section{Anahtar Kelimeler}

Ahududu

Yozgat

Adaptasyon

\section{Determination of Adaptation Capabilities of Some Raspberry Varieties in Yozgat Ecology}

\section{ABSTRACT}

This study was conducted to determine the adaptation skills of Heritage, Aksu Pembesi, Hollanda Boduru and Ruby raspberry varieties in Yozgat ecological conditions between 2017-2018. The performances of the varieties were evaluated by examining phenological observations, plant characteristics and some fruit quality criteria. In terms of yield per shoot, Heritage gave the best results $\left(177.85-337.34 \mathrm{~g} \mathrm{piece}^{-1}\right)$ for both years. With regards to average fruit weight, in the first year of experiment, there was no significant difference, but in the second year, Ruby (2.32 g) and Aksu Pembesi $(2.21 \mathrm{~g})$ have the highest average fruit weight in the same group. When the two-year data of water-soluble dry matter, titratable acidity and vitamin $\mathrm{C}$ contents were evaluated together, Heritage was the prominent variety. When the results of two years of the experiment were evaluated, it was determined that Aksu Pembesi has a faster adaptation to the region than the other varieties in terms of vegetative growth. According to the yield and quality values, it is determined that Heritage has the highest results among the other varieties.

\section{Research Article}

$\begin{array}{ll}\text { Article History } & \\ \text { Received } & : 26.02 .2019 \\ \text { Accepted } & : 16.05 .2019\end{array}$

\section{Keywords \\ Raspberry \\ Yozgat}

Adaptation

To Cite : Balcı G, Keles H 2019. Bazı Ahududu Çeşitlerinin Yozgat Ekolojisinde Adaptasyon Yeteneklerinin Belirlenmesi. KSÜ Tarım ve Doğa Derg 22(6): 823-829. DOI: 10.18016/ksutarimdoga.vi.532643.

\section{GİRIŞ}

Türkiye'de son 30 yıl içerisinde önem kazanan üzümsü meyveler iç ve dış ticarette sürekli talep gören ve yüksek fiyatlara alıcı bulabilen meyve türleridir (Onur, 2006). Çilek dışında kalan üzümsü meyvelerin ticari anlamda yetiştiricilikleri elma, armut gibi kültür bitkileri ile kıyaslandığında oldukça yeni ve az miktarlarda yapılan bir tarım koludur. Ancak üzümsü meyveler grubuna giren birçok bitkinin yabani formlarına Türkiye'ni değişik yörelerinde sıkça rastlanılmaktadır. Yabani popülasyondaki zenginlik, bu bitki türüne ait kültür çeşitlerinin Türkiye'de yetişebileceğini göstermektedir (Eyduran ve ark., 2006). 
Üzümsü meyveler grubuna giren Ahududu (Rubus idaeus L.) gülgiller (Rosaceae) familyasından, yaz ve sonbahar mevsiminde kırmızı renkli ve tatlı meyveler veren bir bitki türüdür. Ayrıca fenoller, flavonlar, flavonoidler, vitaminler ve antioksidanlar bakımından da zengindir (Kähkönen ve ark., 1999; Halvorsen ve ark., 2001). Ahududular her yll düzenli ürün vermeleri ve yetiştiriciliklerinin kolay olması, taze tüketiminin yanında reçel, marmelat, içecek, dondurulmuş gıda ve konserve üretimi gibi endüstriyel ürün olarak değerlendirilebilmesi ve küçük bahçe işletmelerinde taze olarak satış imkânlarının bulunması nedeniyle çok önemli bir yere sahiptirler (Pehluvan ve Güleryüz, 2004).

Dünya ahududu üretimi 2016 yılında 795.249 ton olmuştur. Bu üretimde 164602 ton ile Rusya ilk sirada yer alırken ABD (137.829 t) ve Polonya (129.063 t) Rusya'yı izlemektedir. (FAO, 2018). Türkiye'de ise toplam $4.989 \mathrm{t}$ ahududu üretilmekte olup üretimin hemen tamamı Bursa ilinde yapılmaktadır (TÜIK, 2018a). Amerika ve Meksika gibi önemli ahududu üreticisi ülkelerin birim alandaki verimleri sirasıyla $1.572 \mathrm{~kg} \mathrm{da}{ }^{-1}$ ve $1.814 \mathrm{~kg} \mathrm{da}^{-1}(\mathrm{FAO}, 2018)$ iken Türkiye'de bu rakamlarm $843 \mathrm{~kg}$ da $^{-1}$ seviyelerinde kalmıştır. $\mathrm{Bu}$ durum ahududu yetiştiriciliğinin modern yetiştiricilik tekniklerinden uzak ve amatör olarak yapılması ile, kapama ahududu bahçelerinin olmamasından kaynaklanmaktadır (İpek ve ark., 2018). Farklı ekolojik koşullarda bitkiler farklı stres faktörlerine maruz kalmakta ve çeşitlerin performansları değişebilmektedir (Aras ve Eşitken 2018). Ahududu üretimi ve birim alandan elde edilen verimin artırılması için bölgelere uygun çeşitlerin belirlenmesi ve bu amaçla adaptasyon çalışmalarının yapılması gerekmektedir.

Türkiye'nin tahıl ambarlarından birisi olan Yozgat ili tarım alanları bakımından da ülkenin 5 . büyük tarım alanına sahiptir (TUIK, 2018b). Daha çok tarla bitkileri ürünlerinin yetiştirildiği Yozgat ilinde bahçe bitkilerine ait türlerin yetiştiriciliği oldukça sınırlıdır. Yabani ve kültür formlarında birçok bahçe bitkisi türünün Yozgat ilinin geneline yayılmış halde bulunması da ilin bu konudaki potansiyelini göz önüne çıkarmaktadır (TÜIK, 2018a). Bu potansiyelin kullanılması ve birim alandan elde edilen gelirin yükseltilmesi amaciyla ekonomik değeri yüksek olan ahududu yetiştiriciliğinin yaygınlaştırılması ve adaptasyon çalışmalarının yapılması önem arz etmektedir.

$\mathrm{Bu}$ sebeple üniversite Tarımsal Uygulama ve Araştırma Merkezi bünyesinde bulunan Gedikhasanlı Araştırma ve Uygulama Alanında dört farklı ahududu çeşidinin bölge ekolojik koşullarına adaptasyon yetenekleri belirlenmiştir.

\section{MATERYAL ve METOT}

\section{Bitkisel Materyal}

Araştırma; TUAM (Tarımsal Uygulama Araştırma Merkezi) kontrolünde bulunan Gedikhasanlı Uygulama ve Araştırma Alanındaki (1111 rakım, 39 $35^{\prime} \quad 07^{\prime \prime}$ kuzey ve $35^{\circ} \quad 09^{\prime} 35^{\prime \prime}$ doğu) parsellerde yürütülmüştür. Denemede kullanılan 4 ahududu çeşidinin özellikleri aşağıda verilmiştir (Demirsoy ve ark., 2006).

Ruby: Bu çeşit yüksek verimli olup Haziran sonlarına doğru ilk hasat yapılmaktadır. Diken yapısı az ve meyvenin aroması iyidir. Yola dayanımı orta seviyededir.

Aksu Pembesi: Meyveleri iri, orta iri açık pembe renkli iyi aromalı, hafif yuvarlak konik şekilli yola dayanımı iyidir.

Heritage: Yüksek verimli, aroması ve tadı iyi olan bu çeşidin kış soğuklarına karşı direnci yüksektir. Bu çeşit yıllık sürgünlerinde de meyve oluşturup yılda 2 ürün vermektedir.

Hollanda Boduru: Orta verimli bir çeşittir. Haritage gibi bu çeşit de yıllık sürgünleri verimli bir çeşittir. Meyvenin raf ömrü uzun olup meyvesi taze tüketime ve şoklamaya uygundur.

\section{Çalışma Alanına Ait Özellikler}

Toprak Özellikleri

Denemenin yürütüldüğü bahçenin toprak özellikleri (Çizelge 1) Avanos Ziraat Odası Başkanlığına ait toprak analiz laboratuvarında belirlenmiştir.

\section{İklim Özellikleri}

Deneme boyunca tespit edilen ortalama aylık sicaklık değerleri Şekil 1 de gösterilmiştir.

Çizelge 1. Deneme alanının bazı toprak özellikleri

\begin{tabular}{lllll}
\hline Analizin Adı & Birimi & Yöntem & Sonuç & Açılklama \\
\hline Toprak Bünyesi & $\%$ & Saturasyon & 55 & Killi-tınlı \\
pH & & Saturasyon & 7.94 & Orta Derecede Alkalin \\
\%Toplam Tuz & $\%$ & Saturasyon & 0.01 & Tuzsuz \\
Kireç $\left(\mathrm{CaCO}_{3}\right)$ & $\%$ & Kalsimetrik & 5.4 & Orta Kireçli \\
Organik $\mathrm{Madde}$ & $\%$ & Walkey-Black & 1.44 & $\mathrm{Az}$ \\
Fosfor $\left(\mathrm{P}_{2} \mathrm{O}_{5}\right)$ & $\mathrm{Kg} \mathrm{da}^{-1}$ & Olisen & 1.78 & Cok Az \\
Potasyum $\left(\mathrm{K}_{2} \mathrm{O}\right)$ & $\mathrm{Kg} \mathrm{da}^{-1}$ & A.Asetat-AAS & 61.15 & Yeterli \\
\hline
\end{tabular}




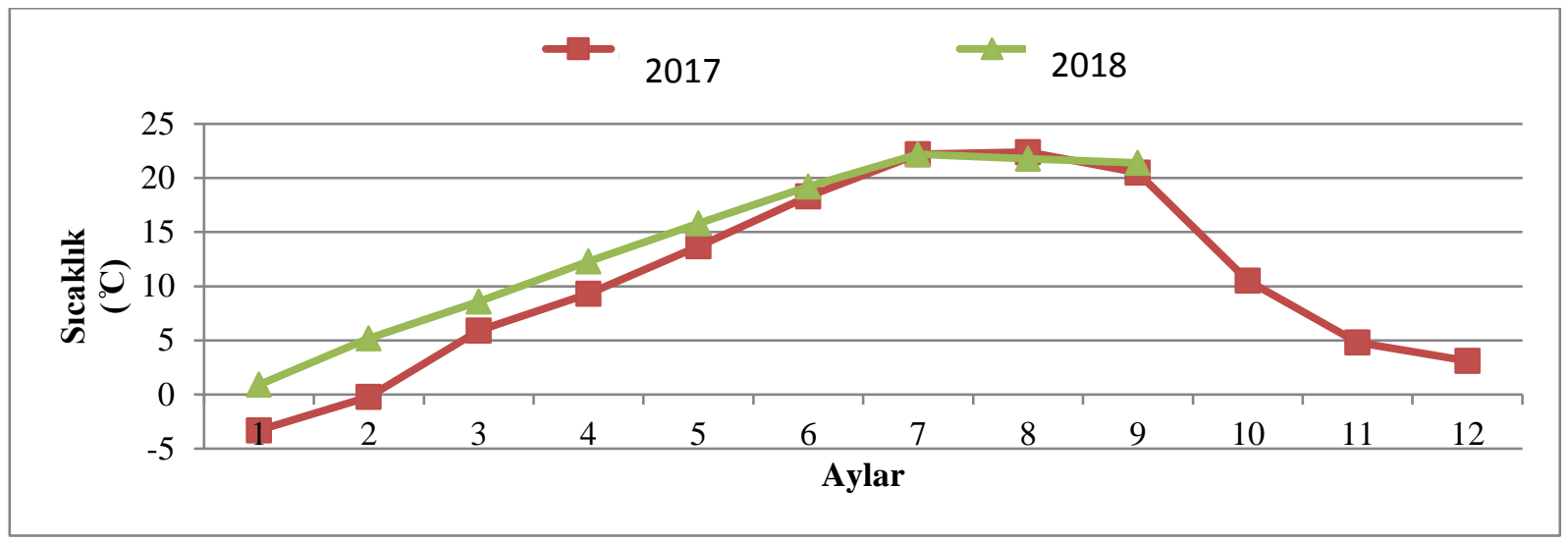

Şekil 1. 2017-2018 yılları ait aylık ortalama sıcaklık değerleri

\section{Deneme Deseni}

Bu çalışma, tesadüf parselleri deneme desenine göre, 3 tekerrürlü ve her tekerrürde 5 bitki olacak şekilde planlanmış olup, bitkiler $1.5 \mathrm{~m}$ sıra üzeri ve $3 \mathrm{~m}$. sıra arası olacak şekilde 20 Haziran 2016 tarihinde dikilmişlerdir. Deneme alanına 60-40-40 cm'lik mesafelerle yerleştirilen 3 sıra telden oluşan destek sistemi 17.04.2017 tarihlerinde kurulmuştur. Sulama (damlama), ot alma, gübreleme, budama gibi işlemler düzenli olarak yapılmıştır. Deneme kurulmadan önce toprak sonbaharda sürülerek, yanmış ahır gübresi ile toprağa takviye yapılmıştır.

Çalışma Boyunca Yapılan Gözlemler, Ölçümler ve Analizler:

\section{Fenolojik Analizler}

Denemede gözlerin uyanmass, dip sürgünü çıkış tarihi, ilk çiçeklenme (ilk çiçeğin görüldüğü tarih), tam çiçeklenme (\%70'inin açtığı dönem), meyve tutumu(ilk meyvenin görüldüğü tarih) ve hasat tarihi (meyvelerin hasada geldiği ilk tarih) gibi fenolojik gözlemler tespit edilmiştir (Demirsoy, 2006; Eyduran ve ark., 2006).

\section{Bitkisel Analizler}

Bitki başına düşen sürgün sayısı (adet), sürgün uzunluğu $(\mathrm{cm})$, dijital kumpas ile sürgün kalınlığg $(\mathrm{mm})$ ve sürgün başına verim ( $\mathrm{g} /$ sürgün) tespit edilmiştir (Demirsoy ve ark., 2006).

\section{Verim ve Kalite Kriterleri}

\section{Sürgün Başına Verim (g/sürgün)}

Her parselden elde edilen toplam ürün miktarının parseldeki sürgün sayısına bölünmesiyle hesap edilmiştir (Eroğlu vd., 2006; Demirsoy ve ark., 2006). Sadece meyve dallarında elde edilen ürün toplam verim olarak değerlendirilmiştir. Yıllık sürgünlerden elde edilen meyve verimi toplam verim olarak değerlendirilmemiştir.

\section{Ortalama Meyve Ağırlığı (g)}

10 adet meyvenin ağırlığ Veriler 3 tekerrürlü olarak belirlenmiş toplamda her çeşit için 30' ar adet meyve kullanılmıştır (Göktaş ve ark., 2009).

\section{Suda Çözünebilir Kuru Madde (\%)}

Hasadın başından sonuna kadar 3 kez her parselden alınacak olgun meyveden elde edilen meyve suyunda dijital refraktometre ile okunarak saptanmıştır (Kılıç ve ark., 1991; Eyduran ve ark., 2006).

\section{Titre Edilebilir Asit (\%)}

Hasadın başından sonuna kadar farklı dönemlerde 3 kez her parselden alınacak olgun meyvelerin sıkılması ile elde edilen $5 \mathrm{ml}$ meyve suyunda titrasyon asitliği yöntemi ile belirlenmiştir (Kılı̧ ve ark., 1991; Eroğlu ve ark., 2006).

\section{Vitamini İçeriği (mg 100ml-1)}

Denemenin her iki yılında hasadın başından sonuna kadar 3 kez alınan meyve örnekleri spektrofotometrede okunarak C vitamini belirlenmiştir (Kılıç ve ark., 1991).

\section{İstatistiksel Analizler}

Araştırma süresince elde edilen tüm verilerin ortalamalarının hesaplanmasında ve grafiklerinin çizilmesinde "Microsoft EXCEL" programı kullanılmış, istatistikî analizler SPSS 20.0 (SAS Inc.) paket programında değerlendirilmiştir. İstatistiksel analiz sonucunda farklılık gösteren ortalamalar arasındaki farklılığın belirlenmesinde aynı paket programı kullanılarak Duncan çoklu karşılaştırma testi (Duncan Multiple Range Test) uygulanmıştır. Sonuçların, istatistiksel değerlendirilmesinde farklar arasındaki önemlilik düzeyi 0.05 olarak belirlenmiştir.

\section{BULGULAR ve TARTIŞMA}

\section{Fenolojik Gözlemler}

Denemenin ilk yılında Ruby ilk çiçeklenen ahududu çeşidi olurken (23.05.2017) en geç çiçeklenen çeşit Hollanda Boduru (15.06.2017) olmuştur. Genel de çeşitlerin mayısın son haftası ve haziran ortasında çiçeklendiği görülmüştür. İlk hasada gelen çeşit Heritage (10.07.2017) olurken en geç hasat olgunluğuna gelen çeşit Hollanda Boduru (20.07.2017) 
olmuştur (Çizelge 2). 2018 yılına bakıldığında da ilk çiçeklenen çeşit Ruby olurken (08.03.2018) en geç çiçeklenen çeşit Hollanda Boduru (28.05.2018) olmuştur (Çizelge2). Denemenin ikinci yılında hasat olgunluğuna gelen ilk çeşit Heritage olurken (13.06.2018) en geç hasat olgunluğuna Hollanda Boduru (07.07.2018) gelmiştir (Çizelge2). İkinci yılda bütün çeşitler yaklaşı 15-20 gün erken çiçeklenmiştir. Bunun nedeni 2018 yılı ortalama sıcaklık değerlerinin tüm ülkede olduğu gibi Yozgat ilinde de 2017 yılı değerlerine göre yüksek seyretmesi olarak açıklanabilir (Şekil 1). Demirsoy ve ark. (2006)' nın Samsun ekolojisinde yaptıkları ahududu adaptasyon çalışmasına göre, Yozgat koşullarında Heritage çeşidi aynı zamanlarda çiçeklenirken diğer çeşitlerin çiçeklenme tarihleri yaklaşık 1 ay daha geç gerçekleştiği saptanmıştır. Dolayısıyla Heritage dışında kalan diğer çeşitler Yozgat ekolojik koşullarında Samsun ekolojik koşullarına göre yaklaşık 1 ay daha geç hasada gelmiştir. Bu denemede çiçeklenme tarihi diğer çeşitlere göre daha geç olan Hollanda Boduru çeşidi, Türemiş ve ark. (2006)' nın Adana'da yaptıkları ahududu adaptasyon çalışmasında en erken çiçeklenen çeşit olmuştur. Yine aynı çalışmada mayıs ayının son haftasında hasada gelen Heritage çeşidi yapılan çalışmada temmuz ayının son haftasında hasat olumuna gelmiştir. Ankara koşullarında yapılan ahududu adaptasyonu çalışmasında ise bu çalışmada kullanılan çeşitler Yozgat ekolojisi ile kıyaslandığında 15 gün erken çiçeklenmeye başlamış ve dolayısıyla 15 gün önce hasada gelmiştir (Eydural ve ark., 2006). Çalışmanın sonuçları yapılmış diğer adaptasyon çalışmaları ile benzerlik göstermekle birlikte Yozgat koşullarında çiçeklenme ve hasat tarihleri gibi fenolojik verilerin Adana, Samsun ve Ankara illerine göre daha geç olması ortalama sıcaklık verilerinin Yozgat ilinde diğer illere kıyasla daha düşük olmasından kaynaklandığını düşündürmektedir. Fenolojik gözlemler ekoloji ve çeşit gibi faktörlerden etkilenerek bölgelere göre farklılık gösterebilmektedir (Ağaoğlu ve ark., 1997). Türemiş ve ark. (2006) Adana koşullarında derim süresinin uzun, uyanma ve hasada gelme tarihlerinin ise erken olmasını iklim koşullarının sıcak olmasından kaynaklandığını bildirmişlerdir.

Çizelge 2. Yozgat koşullarında denemeye alınan ahududu çeşitlerinde 2017-2018 yıllarına ait bazı fenolojik gözlemler

\begin{tabular}{|c|c|c|c|c|c|c|c|c|c|c|c|c|}
\hline \multirow[t]{2}{*}{ ÇEŞİT } & \multicolumn{2}{|c|}{$\begin{array}{l}\text { Gözlerin } \\
\text { belirginleşmesi }\end{array}$} & \multirow{2}{*}{$\begin{array}{l}\begin{array}{l}\text { Dip } \\
\text { çıkışı }\end{array} \\
2017\end{array}$} & \multirow{2}{*}{$\begin{array}{c}\text { sürgün } \\
2018\end{array}$} & \multicolumn{2}{|c|}{$\begin{array}{l}\text { İlk } \\
\text { çiçeklenme }\end{array}$} & \multicolumn{2}{|c|}{$\begin{array}{l}\text { Tam } \\
\text { çiçeklenme }\end{array}$} & \multicolumn{2}{|c|}{$\begin{array}{l}\text { İlk Meyve } \\
\text { tutumu }\end{array}$} & \multicolumn{2}{|c|}{ Hasat tarihi } \\
\hline & 2017 & 2018 & & & 2017 & 2018 & 2017 & 2018 & 2017 & 2018 & 217 & 018 \\
\hline ul & 18.04 & 11.04 & 18.04 & 10.04 & 23.05 & 08.05 & 30.05 & 26.05 & 28.05 & 17 & 07 & \\
\hline $\begin{array}{l}\text { Aksu } \\
\text { Pembesi }\end{array}$ & 18.04 & 18.04 & 18.04 & 15.04 & 25.05 & 11.05 & 01.06 & 19.05 & 30.05 & 18.05 & 15.07 & 26.06 \\
\hline Heritage & 18.04 & 11.04 & 18.04 & 05.03 & 10.06 & 20.05 & 18.06 & 04.06 & 15.06 & 27 & 7 & 13.0 \\
\hline $\begin{array}{l}\text { Hollanda } \\
\text { Boduru }\end{array}$ & 18.04 & 11.04 & 25.04 & 05.04 & 15.06 & 28.05 & 21.06 & 12.06 & 10.06 & 09.06 & 20.07 & 07.07 \\
\hline
\end{tabular}

\section{Bitkisel Özellikler}

$\mathrm{Bu}$ çalışmada yıllar arasında bitkisel özellikler karşılaştırıldığında farklı sonuçlar görülebilmektedir (Çizelge 3).

2017 yılında çeşitler arasında bitki başına ortalama sürgün sayıları incelendiğinde en fazla sürgün veren çeşidin 10.25 adet ile Hollanda Boduru olduğu, en az sürgün veren çeşidin ise 2.58 adet ile Heritage çeşidi olduğu belirlenmiştir. 2018 yılında ise en fazla sürgün Ruby (19.33 adet) çeşidinden, en az sürgün 2017 yılında olduğu gibi Heritage çeşidinden (11.13 adet) alınmıştır. Yozgat ekolojisine yakın özellikler gösteren Ayaş (Ankara) ekolojik koşullarında, Eyduran ve ark., (2006)' nin yürütmüş oldukları denemede ilk sene en yüksek sürgün sayısı Hollanda Boduru çeşidinden (22.2 adet) en düşük sürgün sayısı Heritage çeşidinden (15.2 adet) ikinci sene ise en yüksek sürgün sayısı Ruby ve Aksu Pembesi çeşitlerinden (sırasıyla 20.8 ve 20.3 adet) elde edilirken en az sürgün sayısı Heritage çeşidinden (18.3 adet) elde edilmiş ve bu deneme benzer sonuçlar alındığı bildirilmiştir.

Sürgün uzunluğu bakımından denemenin iki yılında da Aksu Pembesi en uzun sürgünlere $(90.10 \mathrm{~cm}$ ve $98.12 \mathrm{~cm}$ ) sahip olmuştur. Hollanda Boduru çeşidi ise iki yılda da en kısa sürgünlere sahip çeşit olmuştur. (60 $\mathrm{cm}$ ve $68.41 \mathrm{~cm})$. Ruby çeşidi ise Aksu Pembesi' nden sonra en uzun sürgünlere sahip çeşit olmuştur. Ayaş (Ankara) ve Samsun ekolojik koşullarında yürütülen adaptasyon çalışmalarında sırasıyla Aksu Pembesi ve Ruby çeşitleri en uzun sürgünlere sahip çeşitler olmuşlardır (Demirsoy ve ark., 2006; Eyduran ve ark., 2006). Bu çalışmalarda en kısa sürgün uzunluğuna sahip çeşitler ise sirasıyla Heritage ve Hollanda Boduru olmuştur. Elde edilen bu sonuçlar Yozgat iline yakın Ankara ve Samsun illerinde yapılmış çalışmalar ile benzerlik göstermiştir.

Sürgün kalınlıkları ile ilgili sonuçlar incelendiğinde bu çalışmada her iki yılda da en iyi gelişim gösteren çeşitler Aksu Pembesi ve Ruby olmuştur. Eyduran ve ark. (2006)' in Ankara ekolojik koşullarında yaptıkları çalışmada en kalın sürgünlere sahip çeşit Ruby olurken, Demirsoy ve ark. (2006)' nin Samsun koşullarında yaptıkları çalışmada Heritage en kalın sürgünlere sahip çeşit olmuştur. Her iki çalışmada da 
en ince sürgünler Hollanda Boduru çeşidinden elde edilmiştir. Eroğlu ve Gerçekçioğlu (2006)' nun yaptıkları çalışmada da benzer sonuçlar alınmış, sürgün kalınlığı en düşük olan çeşidin Hollanda Boduru olduğu bildirilmiştir.

Ahududu çeşitlerinin 2017 yılı sürgün başına verimleri incelendiğinde Heritage $177.85 \mathrm{~g}$ ile sürgün başına verim bakımından en iyi sonuç veren çeşit olurken sürgün başına en düşük verim Aksu Pembesi ile Hollanda Boduru çeşitlerinden elde edilmiştir (Çizelge 3). 2018 yılında ise yine sürgün başına en yüksek verim Heritage çeşidinden (337.34 g) elde edilirken en düşük verim Hollanda Boduru çeşidinden (98.29 g) elde dilmiştir. Demirsoy ve ark. (2006) Samsun'da yaptıkları ahududu adaptasyon çalışmasında en yüksek verimi Heritage çeşidinden alırken en düşük verimi Aksu Pembesi' nden elde edilmiştir. Adana koşullarında yürütülen ahududu adaptasyon çalışmasında sürgün başına verim bakımından en iyi sonucu Heritage çeşidi verirken verimi en düşük çeşit Ruby olarak belirlenmiştir (Türemiş ve ark., 2006). Ankara koşullarında yapılan adaptasyon çalışmasında ise sürgün başına en yüksek verim Aksu Pembesi nden elde edilirken en düşük verim Ruby çeşidinden elde edilmiştir (Eyduran ve ark., 2006).

Çizelge 3. Yozgat koşullarında denemeye alınan ahududu çeşitlerinde 2017-2018 yıllarına ait bazı bitkisel özellikler

\begin{tabular}{lllllllll}
\hline ÇEŞIT & \multicolumn{2}{l}{$\begin{array}{l}\text { Sürgün sayısı bitki } \\
\text { (adet) }\end{array}$} & \multicolumn{2}{l}{ Sürgün uzunluğu (cm) } & Sürgün Kalınlı̆̆ $(\mathrm{mm})$ & \multicolumn{2}{l}{$\begin{array}{l}\text { Sürgün başına verim } \\
\left.\text { (g adet }^{-1}\right)\end{array}$} \\
\hline & 2017 & 2018 & 2017 & 2018 & 2017 & 2018 & 2017 & 2018 \\
Ruby & $3.64 \mathrm{c}^{*}$ & $19.33 \mathrm{a}$ & $90.00 \mathrm{a}$ & $96.64 \mathrm{~b}$ & $8.10 \mathrm{a}$ & $8.39 \mathrm{a}$ & $123.18 \mathrm{~b}$ & $152.18 \mathrm{~b}$ \\
$\begin{array}{l}\text { Aksu } \\
\text { Pembesi }\end{array}$ & $4.53 \mathrm{~b}$ & $15.20 \mathrm{~b}$ & $90.10 \mathrm{a}$ & $98.12 \mathrm{a}$ & $8.12 \mathrm{a}$ & $8.32 \mathrm{a}$ & $115.72 \mathrm{c}$ & $131.73 \mathrm{c}$ \\
$\begin{array}{l}\text { Heritage } \\
\text { Hollanda } \\
\text { Boduru }\end{array}$ & $2.58 \mathrm{~d}$ & $11.13 \mathrm{~d}$ & $70.01 \mathrm{~b}$ & $79.38 \mathrm{c}$ & $7.00 \mathrm{~b}$ & $6.99 \mathrm{~b}$ & $177.85 \mathrm{a}$ & $337.34 \mathrm{a}$ \\
\hline
\end{tabular}

*Aynı sütunda farklı harflerle ifade edilen ortalamalar arasında \%5 düzeyinde farklılık vardır

Çeşit özelliklerine de bağlı olmakla birlikte sürgün sayısı, boyu ve bitki verimi gibi bitkisel özellikler ekolojik koşullara göre değişkenlik gösterebilmektedir (Hall, 1990). Heritage ve Hollanda Boduru çeşitleri hem meyve dalları hem de yıllık sürgünleri verimli çeşitlerdir. Ancak yıllık sürgünlerden alınan verim sonbahar dönemine denk gelmektedir. Yozgat ekolojik koşullarında bu dönemde alınan verim ve meyve kalitesi istenilen düzeyde olmamaktadır. Bu sebeple bu çalışmada sadece meyve dallarından alınan verimler karşılaştırılmıştır. Özellikle bitki büyüme ve gelişiminde sıcaklık önemli etkenlerden birisidir ( Porter ve Moot, 1998). Bitkisel özellikler konusunda elde edilen sonuçların yapılmış çalışmalar ile benzerlik göstermiş olması yanında var olan rakamsal farklılıklar bölgeler arasinda mevcut ekolojik farklardan meydana gelmiş olduğu öngörülmektedir.

\section{Pomolojik Özellikler}

Denemede meyveler için önemli kalite kriterleri olan SÇKM, titre edilebilir asitlik, $\mathrm{C}$ vitamini değerleri ve çeşitlerin ortalama meyve ağırlıkları gibi bazı pomolojik özellikler incelenmiştir.

Büyük bir kısmı şekerlerden oluşan SÇKM, meyvelerin kalitelerini belirleyen önemli faktörlerden birisidir (Karaçalı, 1990; Cemeroğlu, 1992). Bu çalışmada incelenen çeşitlere ait SÇKM içerikleri Çizelge 4' de verilmiştir. En yüksek SÇKM içeriğine sahip çeşitler sırasıyla ilk yıl Aksu Pembesi (\%15.70), ikinci yıl ise Ruby (\%14.90) olmuştur. Yapılmış çalışmalar incelendiğinde, Samsun ekolojik koşullarında Heritage çeşidi en yüksek SÇKM değerine (\%10.8) sahip olurken (Demirsoy ve ark., 2006), Adana koşullarında Hollanda Boduru \%7.4 ve Heritage çeşidinin \%6 SÇKM değerine sahip olduğu belirlenmiştir (Türemiş ve ark., 2006). Ankara koşullarında yapılmış çalışmada 12 ahududu çeşidi kullanılmış bu çalışmada da yer alan çeşitler arasında olan Heritage çeşidi (\%20.22) en yüksek SÇKM içeriğini vermiştir (Eyduran ve ark., 2006). Yine Tokat ekolojik koşullarında yapılan bir çalışmada Heritage çeşidinin \%10.06 SÇKM içeriğine sahip olduğu bildirilmiştir (Eroğlu ve Gerçekçioğlu, 2006).

Kaliteyi belirleyen diğer bir faktör ise meyvelerin asit içerikleridir (Moretti ve ark., 1998; Koç ve ark., 2015). Çeşitlerin "Titre Edilebilir Asit" içerikleri Çizelge 4' de verilmiştir. Denemenin ilk yılında en yüksek titre edilebilir asit içeriğine sahip çeşit Aksu Pembesi (\%1.54) olurken 2018 yılında en yüksek değere sahip çeşit Heritage (\%2.74) olmuştur. Türemiş ve ark. (2006) yatıkları çalışmalarında Adana koşullarında Hollanda Boduru' nun \%1.58 ve Heritage çeşidinin \% 0.96 asitlik değerine sahip olduklarını bildirmişlerdir.

Vitamin C bitkilerde büyümeyi düzenleyici olarak görev yapmakla birlikte önemli bir antioksidan kaynağıdır (Garg ve ark., 1972). Ahududular iyi bir C Vitamini kaynağıdırlar. Taze ahududu meyvelerinin yaklaşık olarak 5-40 mg $100 \mathrm{~g}^{-1}$ arasında C Vitamini içerdikleri belirtilmektedir (Skrovankova ve ark., 
2015). Vitamin içerikleri bakımından çilek ve böğürtlen meyveleriyle benzerlik göstermektedirler (De Ancos ve ark., 2000; Benvenuti ve ark., 2004). Bu çalışmada yıllar arasında farklar tespit edilmiş (Çizelge 4) ilk yıl verilerinde en yüksek C Vitamini içeriği Heritage çeşidinde $\left(65.23 \quad \mathrm{mg} \quad 100 \mathrm{~g}^{-1}\right)$ belirlenirken denemenin ikinci yllında en yüksek $\mathrm{C}$ Vitamini içeriği önceki yll en düşük içeriğe sahip olduğu belirlenen Aksu Pembesi çeşidinde $(57.28 \mathrm{mg}$ $100 \mathrm{~g}^{-1)}$ tespit edilmiştir. Ancos ve ark. (2000), yaptıkları bir çalışmada ahududu çeşitlerinin $\mathrm{C}$ Vitamini içeriğinin $22.10^{-} 31.20 \mathrm{mg} 100 \mathrm{~g}^{-1}$ arasında değiştiğini bildirmişlerdir. Bu çalışmada belirlenen $\mathrm{C}$ Vitamini içeriklerinin literatüre nazaran biraz daha yüksek olmasının nedeninin ekolojinin farklılığ olduğunu düşünmekteyiz. Bitkiler stres koşulları altındayken toksik etki yapan radikallere karş1 askorbik asit (C Vitamini), E Vitamini, glutatiyon gibi antioksidan maddeleri kullanırlar ve bünyelerinde artırırlar (Çakmak ve Marschner, 1992). Karasal iklim koşullarına sahip Yozgat ilinde bitkiler soğuk stresine maruz kalabilmekte ve bu nedenle bünyelerinde bazı maddeleri daha fazla sentezleyebilmektedirler. $\mathrm{Bu}$ çalışmada 2017 verilerinin 2018 verilerine oranla daha yüksek çıkmış olması bu şekilde açıklanabilir.
Çeşitlerin sahip oldukları meyve ağırlıkları bitkilerin verim ve kalite kriterleri arasinda bulunan ve adaptasyon çalışmalarında genellikle incelenen önemli özelliklerden birisidir (Eroğlu ve Gerçekçioğlu, 2006; Eyduran ve ark., 2006; Göktaş ve ark., 2009). Yapılan çalışmada çeşitlerin meyve ağırlıkları arasında ilk yıl verileri açısından istatistiki bir fark bulunamamıştır. Denemenin ikinci yılında sonuçlar arasında istatistiki farklar belirlenmiş aynı gruba giren Ruby ve Aksu Pembesi en yüksek ortalama meyve ağırlığına (2.32 g ve $2.21 \mathrm{~g})$ sahip çeşitler olmuşlardır. Göktaş ve ark. (2009), Eğirdir yöresinde 12 farklı ahududu çeşidinin adaptasyon yeteneklerini belirlemişler ve bu çalışmada en yüksek ortalama meyve ağırlığını Tulameen çeşidinde $(3.19 \mathrm{~g})$ belirlemişlerdir. $\mathrm{Bu}$ çalışmada Ruby, Hollanda Boduru, Aksu Pembesi ve Heritage çeşitleri de incelenmiş iki yıl süren çalışmada ortalama meyve ağırlıkları sirasıyla $1,87 \mathrm{~g}, 1,85 \mathrm{~g}, 1,84 \mathrm{~g}$ ve $1.52 \mathrm{~g}$ olarak tespit edilmiştir. Yozgat ili ile benzer ekolojik özelliklere sahip Ankara (Ayaş) ilinde yapılmış bir çalışmada ise Heritage, Aksu Pembesi, Hollanda Boduru ve Ruby çeşitlerinin ortalama meyve ağırlıkları sırasıyla $1.81 \mathrm{~g}, 1.79 \mathrm{~g}, 1.65 \mathrm{~g}$ ve $1.44 \mathrm{~g}$ olarak tespit edilmiştir (Eyduran ve ark., 2006).

Çizelge 4. Yozgat koşullarında denemeye alınan ahududu çeşitlerinde 2017-2018 yıllarına ait bazı pomolojik özellikler

\begin{tabular}{|c|c|c|c|c|c|c|c|c|}
\hline \multirow[t]{2}{*}{ ÇEŞİT } & \multicolumn{2}{|c|}{$\begin{array}{l}\text { Ortalama } \\
\text { Ağırlığ }{ }_{1}(\mathrm{~g})\end{array}$} & \multicolumn{2}{|c|}{ SÇKM (\%) } & \multicolumn{2}{|c|}{ \%Asitlik } & \multicolumn{2}{|c|}{$\begin{array}{l}\text { C Vitamini (mg 100g } \\
\text { 1) }\end{array}$} \\
\hline & 2017 & 2018 & 2017 & 2018 & 2017 & 2018 & 2017 & 2018 \\
\hline Ruby & $2.11^{\text {öd }}$ & $2.32 \mathrm{a}$ & $13.40 \mathrm{c}$ & $14.90 \mathrm{a}$ & $1.06 \mathrm{c}$ & $2.39 \mathrm{~b}$ & $57.84 \mathrm{~b}$ & $39.92 d$ \\
\hline Aksu Pembesi & 2.01 & $2.21 \mathrm{a}$ & $15.70 \mathrm{a}$ & $13.60 \mathrm{~b}$ & $1.54 \mathrm{a}$ & $1.75 \mathrm{c}$ & $25.48 \mathrm{c}$ & $57.28 \mathrm{a}$ \\
\hline Heritage & 2.05 & $1.46 \mathrm{c}$ & $15.10 \mathrm{ab}$ & $13.40 \mathrm{~b}$ & $1.24 \mathrm{ab}$ & $2.74 \mathrm{a}$ & $65.23 \mathrm{a}$ & $43.03 \mathrm{~b}$ \\
\hline $\begin{array}{l}\text { Hollanda } \\
\text { Boduru }\end{array}$ & 2.23 & $1.79 \mathrm{~b}$ & $13.60 \mathrm{c}$ & $10.10 \mathrm{c}$ & $1.43 \mathrm{a}$ & $2.29 b$ & $60.26 \mathrm{~b}$ & $40.52 c$ \\
\hline
\end{tabular}

*Aynı sütunda farklı harflerle ifade edilen ortalamalar arasında \%5 düzeyinde farklılık vardır

\section{SONUÇ}

Son zamanlarda gida sanayisinde görülen büyük gelişmeler her türlü meyve sebzenin değerlendirilmesi ve muhafazasına imkân sağlamaktadır. Gıda sanayisinde oldukça yoğun kullanılan üzümsü meyveler özellikle reçel, marmelat ve pasta yapımında kullanılmaktadır. Son yıllarda yapılan çalışmalara göre üzümsü meyveler insan sağlığı açısından büyük önem taşımaktadır. $\mathrm{Bu}$ nedenlerle önümüzdeki yıllarda üzümsü meyvelere talebin daha çok artması beklenmektedir.

Yapılan bu çalışma ile Yozgat iline uygun ahududu çeşitlerinin belirlenmesi amaçlanmıştır. Denemenin sonuçları incelendiğinde Hollanda boduru dışında kalan diğer ahududu çeşitlerinin yöreye uyum sağlayabildikleri görülmüştür. Ancak istatistiki olarak değerlendirilen veriler ışığında vejetatif büyüme konusunda birbirine yakın özellikler gösteren Aksu Pembesi ve Ruby çeşitlerinin bölgeye daha hızlı uyum sağladığı belirlenmiştir. Sürgün başına meyve verimi değerleri bakımından çalışma sonucunda Heritage çeşidinin en iyi sonuçlara sahip çeşit olduğu tespit edilmiştir. Hollanda Boduru hem vejetatif gelişim hem de verim olarak diğer çeşitlere kıyasla en zayıf gelişim gösteren çeşit olmuştur. Yöre de planlanacak ahududu yetiştiriciliği projelerinde, bu çalışmada adaptasyon yeteneklerinin belirlenmeye çalışıldığı arasından Heritage çeşidinin pomolojik özelliklerin bütünü ve sürgün başına verim kriterleri dikkate alındığında öncelikli olarak değerlendirilmesi önerilmektedir.

\section{TEŞEKKÜR}

Çalışmaya vermiş oldukları maddi desteklerinden ötürü Yozgat Bozok Üniversitesi Bilimsel Araştırma Projeleri birimine teşekkürü borç biliriz (Proje Kodu: $6602 \mathrm{~b}-\mathrm{ZF} / 16-18)$. 


\section{KAYNAKLAR}

Aras S, Eşitken A 2018. Physiological Responses of Cherry Rootstocks to Short Term Salinity. ErwerbsObstbau, 60(2): 161-164.

Ağaoğlu Y S, Çelik H, Çelik M, Fidan Y, Gülşen Y, Günay A, Halloran N, Köksal A İ, Yanmaz R 1997. Genel Bahçe Bitkileri. Ankara Üniv. Zira. Fak. Eğitim, Araştırma ve Geliştirme Vakfı Yayınları, No:4, Ankara.

Ancos B, González EM, Cano M P 2000. Ellagic Acid, Vitamin $\mathrm{C}$ and Total Phenolic Contents and Radical Scavenging Capacity Affected by Freezing and Frozen Storage in Raspberry Fruit. J. Agric. Food Chem., 48 (10): 4565-4570.

Benvenuti S, Pellati F, Melegari M, Bertelli D 2004. Polyphenols, Anthocyanins, Ascorbic Acid, and Radical Scavenging Activity of Rubus, Ribes and Aronia. J. Food Sci., 69: 164-169.

Cemeroğlu B 1992. Meyve ve Sebze İsleme Endüstrisinde Temel Analiz Metodları. Biltav Yayınları, Ankara, $381 \mathrm{~s}$.

Çakmak I, Marschner H 1992. Magnesium Defficiency and Higlight Intensity Enhance Activities of Superoxide Dismutase, Ascorbate Peroxidase and Glutathione Reductase in Bean Leaves. Plant Physiol., 98:1222-1226.

De Ancos B, Gonzáles EM, Cano MP 2000. Ellagic Acid, Vitamin C, And Total Phenolic Contents And Radical Scavenging Capacity Affected By Freezing And Frozen Storage in Raspberry Fruit. J. Agric. Food Chem., 48. 4565-4570.

Demirsoy L, Demirsoy H, Bilgener Ş, Ersoy B, Öztürk A, Balcı G, Celikel G 2006. Samsun'da Yapılan Ahududu Çeşit Adaptasyon Çalışmaları. II. Ulusal Üzümsü Meyveler Sempozyumu, 14-16 Eylül, 205211, Tokat.

Eroğlu Z, Gerçekçioğlu R 2006. İki Ürün Veren Bazı Ahududu ( $R$. ideaus L.) Çeşitlerinin Tokat Koşullarındaki Performansları. II. Ulusal Üzümsü Meyveler Sempozyumu, 14-16 Eylül, 244-249, Tokat.

Eyduran SP, Ağaoğlu SY, Çelik M 2006. Bazı Ahududu Çeşitlerinin Ayaş (Ankara) Koşularına Adaptasyonu Üzerine Araştırmalar. II. Ulusal Üzümsü Meyveler Sempozyumu, 14-16 Eylül, 224230, Tokat.

FAO 2018. Faostat. http://www.fao.org/faostat/ en/\#data/QC. (Erişim Tarihi: 23.10.2018).

Garg OP, Kapoor V 1972. Retardation of Leaf Senescence by Ascorbic Acid. Journal of Experimental Botany, 23(76): 699-703.

Göktaş A, Demirtaş İ, Atasay A 2009. Bazı Ahududu Çeşitlerinin Eğirdir (Isparta) Yöresine Adaptasyonu. III. Ulusal Üzümsü Meyveler Sempozyumu, 10-12 Haziran, 120-125, Kahramanmaraş.

Hall HK 1990. Blackberry Breeding. Plant Breeding Rev., 8: 249-312.
Halvorsen BLK, Holte MCW, Myhrstad I, Barikmo E, Hvatttum SF, Remberg AB, Wold Haffner $\mathrm{H}$, Baugerod LF, Andersen J, Moskaug DR, Blomhoff JR 2001. A Systematic Screening of Total Antioxidants in Dietary Plants. American Society for Nutritional Sciences, 461-471.

İpek M, Arıkan Ş, Eşitken A, Pırlak L 2018. Bitki Gelişimini Artırıcı Rizobakterilerin "Heritage" Ahududu (Rubus idaeus L.) Çeşidinde Bitki Gelişimi, Verim ve Meyve Kalitesi Üzerine Etkisi. Yüzüncü Yıl Üniversitesi Tarım Bilimleri Dergisi, 28(1): 42-48.

Kähkönen MP, A I Hopia, HJ Vuorela, JP Rauha, K Pihlaja, TS Kujala, M Heinonen 1999. Antioxidant Aktivity of Plant Extracts Containing Phenolic Compounds. J. Agri. Food Chem., (47): 3954-3962.

Karaçalı İ 1990. Bahçe Ürünlerinin Muhafazası ve Pazarlanması. E.Ü. Basımevi, 413 s., Bornovaİzmir.

Kılıç O, Çopur UÖ, Görtay Ş 1991. Meyve ve Sebze İşleme Teknolojisi Uygulama Kılavuzu. Uludağ Üniversitesi Ziraat Fakültesi Ders Notları.

Koç A, Balcı G, Ertürk Y, Keles H, Bakoğlu N 2015. Effects of Microorganism Application on Fruit Quality of San Andreas Strawberry Cultivars Under Different Salinity Conditions. Tarım Bilimleri Araştırma Dergisi, 8 (2): 47-51.

Moretti CL, Sargent SA, Huber DJ, Calbo AG, Puschmann R 1998. Chemical Composition and Physical Properties of Pericarp, Locule and Placental Tissues of Tomatoes with Internal Bruising. Journal of the American Society for Horticultural Science, 123: 656-660

Onur C 2006., Ahududu Yetiştiriciliği. Damla Ofset, Antalya, 100s.

Pehluvan M, Güleryüz M 2004. Ahududu ve Böğürtlenlerin İnsan Sağlığı Açısından Önemi. Bahçe, 33(1-2): 51-57.

Porter JR, Moot DJ 1998. Research Beyond The Means Climatic Variability and Plant Growth. COST Symposium on Applied Agrometeorology and Agroclimatology. In press.

Skrovankova S, Sumczynski D, Mlcek J, Jurikova T, Sochor J 2015. Bioactive compounds and antioxidant activity in different types of berries. International Journal of Molecular Sciences, 16(10): 24673-24706.

TÜİK 2018a. Meyveler, içecek ve Baharat Bitkileri. http://www.tuik.gov.tr/PreTablo.do?alt_id=1001. (Erişim Tarihi: 23.10.2018).

TÜİK 2018b. Bitkisel Üretim İstatistikleri. https://biruni.tuik.gov.tr/medas $/$ /kn=92\&locale=tr. (Erişiom Tarihi: 24.12.2018).

Türemiş NF, Burğut A, Iğdırlı D, Doğan Y, Çalışkan M 2006. Bazı Ahududu Çeşitlerinin Adana Koşullarına Adaptasyonu. II. Ulusal Üzümsü Meyveler Sempozyumu, 14-16 Eylül, 212-218, Tokat. 